Заячківська О. В. [1; ORCID ID: 0000-0002-8792-9204], к.е.н., доцент кафедри фінансів та економічної безпеки Хібеба Б. М. ${ }^{[1]}$, здобувач вищої освіти першого (бакалаврського) рівня

${ }^{1}$ Національний університет водного господарства та природокористування, м. Рівне

\title{
ВАЛЮТНІ ОПЕРАЦІЇ У КОНТЕКСТІ ЗОВНІШНЬОЕКОНОМІЧНОЇ ДІяЛЬНОСТІ
}

Публікацію присвячено вивченню тенденцій валютного регулювання в Україні. Проведено детальний аналіз особливостей здійснення валютного регулювання. У статті основну увагу приділено введенню в дію нового Закону України «Про валюту і валютні операції», який прийнято на зміну Декрету «Про систему валютного регулювання», надано порівняння їх основних положень. Окреслено ключові проблеми, які впливають на розвиток валютних операцій. На підставі проведеного дослідження автори пропонують напрями вдосконалення механізму валютного регулювання.

Ключові слова: валютне регулювання; зовнішньоекономічна діяльність; валютні операції.

Постановка проблеми. Розвиток торгівлі іноземною валютою в Україні $€$ дуже ризикованим. Важливі дослідження в цій галузі демонструють неефективність сучасної світової валютно-фінансової системи та вносять глобальні зміни до ключових факторів. Як один 3 основних елементів системи в останні десятиліття, валютний ринок характеризується наростаючим процесом глобалізації, диверсифікації та трансформації. Валютна політика країни безпосередньо впливає на її економічний розвиток - від окремих галузей до позицій світового ринку.

Аналіз останніх досліджень і публікацій показав, що проблемні аспекти валютного ринку та функціонування валютної системи були визначені в наукових працях таких зарубіжних вчених, як Р. Маккіннон, С. Моісеєвої, М.Фрідмен, А. Шварц та ін. Серед українських вчених необхідно відмітити праці О.Барановського, Я. Белінської, Т. Вахненко, В.Геєця, А. Даниленко, О. Дзюблюка, В. Козюка, Д. Лук'яненко, 3. Луцишин, М. Савлука.

Виділення не вирішених раніше частин загальної проблеми. Авторам необхідно здійснити дослідження теоретичних та 
практичних реалій з'ясування проблемних питань, щодо стану розвитку валютних операцій в Україні.

Виклад основного матеріалу. Перш за все необхідно з'ясувати, що «валютна операція - це операція, яка пов'язана з переходом права власності на валютні цінності та (або) права вимоги і пов'язаних з цим зобов'язань, предметом яких $€$ валютні цінності, між резидентами, нерезидентами, а також резидентами i нерезидентами, крім операцій, що здійснюються між резидентами, якщо такими валютними цінностями є національна валюта, торгівля валютними цінностями, транскордонний переказ валютних цінностей та транскордонне переміщення валютних цінностей» [1].

У своїй роботі К. І. Новікова зазначає, що здійснення поточної та строкової торгівлі валютою в Україні сьогодні і, як наслідок, можливість здійснення хеджування валютного ризику $€$ досить складним явищем. Безумовно, це пов'язано 3 існуючими законодавчими та нормативними обмеженнями на валютному ринку. Дослідження автора у цій галузі показують, що нинішні обмеження призводять до скорочення валютних позицій, суттєво зменшуючи здатність банківських установ здійснювати валютні операції та обмежуючи їх можливість вільно розпоряджатися фізичними та юридичними особами. Реалізація досить жорсткої політики державними регуляторами може бути виправдана нестабільною ситуацією на валютному ринку та поточною фінансовою кризою [2].

П.І.Віблій, Г.В.Горбова, Б.А. Федак у своїх дослідженнях розглядали основні питання валютних операцій та створювали стратегічну програму розвитку національної економіки. Сюди слід включити національні настанови та способи подолання соціальноекономічних проблем [3].

На ситуацію на українському валютному ринку негативно впливає тінізація економіки, знижуючи ефективність заходів валютного регулювання державного банку, а тіньовий рівень становить близько 50\%. Щоб нейтралізувати тінізацію, потрібно посилити контроль над бюджетною сферою. Це означає підвищення прозорості державних закупівель, реформування податкової системи для повернення ПДВ та розробку ефективних антикорупційних програм.

Стосовно нашої держави, то починаючи з 19 лютого 1993 р., діяльність із питань валютного регулювання підпорядковувалася Декрету Кабінету Міністрів України «Про систему валютного регулювання». Нормативно-правове поле, що склалося в 90-ті роки минулого сторіччя, дозволяло перелік лише окремих валютних 
операцій. Водночас інші операції, які не зазначені в Декреті, були заборонені. Такий жорсткий контроль валютного законодавства на початку незалежності України мав на меті зменшити відплив капіталу за кордон, що було необхідним для того, щоб утримати національну економіку. Система валютного регулювання була непрозорою для суб'єктів валютних операцій та створювала додаткові труднощі при вступі у валютні правовідносини. Декрет КМУ містив досить жорсткі умови реєстрації в Національному банку України, зміни сторони в договорі позики між українською компанією й компанією нерезидентом (нерезидента позикодавця зобов'язували подати до банку договори, які підтверджували умови заміни позикодавця, що зарубіжні партнери вважали конфіденційною інформацією та відмовлялись розголошувати ці дані). Таким чином, вітчизняна компанія залишалася в скрутному становищі [4]. На зміну Декрету прийшов Закон України «Про валюту і валютні операції». Метою нового законодавства стало послаблення валютного контролю в державі, спрощення проведення операцій валютного обміну в банках, зміна умов міжнародних переказів. На відміну від Декрету, новий Закон надає чітке ви значення валютному регулюванню - «це діяльність Національного банку України та Кабінету Міністрів України, яка спрямована на регламентацію здійснення валютних операцій суб'єктами валют них відносин і уповноваженими установами» [1].

Також вчені зазначають, що стрімкі зміни курсів валют негативно впливають на національну економіку, і в Україні це явище зараз є дуже поширеним та актуальним. Вирішити цю ситуацію можна лише за допомогою ефективної монетарної політики, тобто переходу інфляційного таргетування до монетарного режиму. Успішне виконання цілей щодо інфляційного таргетування вимагає швидких змін у макроекономічній та структурній політиці, вдосконалення національної статистики та реформ у банківській системі та на внутрішніх фінансових ринках [3].

Такі несприятливі умови й стали основними причинами введення в дію нового законодавства щодо валютного регулювання. Нові постанови Національного банку України на основі Закону України «Про валюту і валютні операції» засвідчують, що громадянам дозволено проводити будь-які операції з іноземною валютою, які прямо не заборонені законодавством. Ще до затвердження Закону України «Про валюту і валютні операції» Правлінням Національного банку України оприлюднено проєкт Положення «Про заходи захисту та визначення порядку здійснення окремих операцій в іноземній валюті» від 02.01.2019р., яке має 
тимчасовий характер i передбачає поступовий перехід до пом'якшення валютного контролю. У Положенні зазначено таке [5]:

- збільшення граничних строків розрахунків з експорту та імпорту товарів до 365 днів, тобто в два рази;

- введено нову систему електронних елімітів, яка замінює систему отримання індивідуальних ліцензій на окремі валютні операції, що могло займати 1-2 місяці. Така процедура дасть змогу населенню інвестувати свої фінанси за кордон у цінні папери або нерухомість;

- з'являється перспектива валютного обміну онлайн до 150 тис. грн в еквіваленті на календарний день;

- виникає можливість обміну валюти за допомогою ПТКС (платіжний термінал + банкомат);

- спрощений нагляд за валютними операціями на суму до 150 тис. грн на календарний день;

- дозволяється фізичним особам, юридичним особам і фізичним особам - суб'єктам підприємницької діяльності придбання банківських металів без фізичної поставки на суму в еквіваленті до 150 тис. грн протягом одного календарного дня в межах банку;

- стає можливим переказ іноземної валюти фізичними особами за кордон до 150 тис. грн без відкриття рахунку;

- скасування необхідності реєструвати в Національному банку України запозичення, залучені від іноземних партнерів.

Загалом Закон України «Про валюту і валютні операції» подається як лібералізація валютного регулювання, однак при детальному дослідженні основних моментів можна виявити низку обмежень, а саме:

- резервування коштів за валютними операціями;

- встановлення граничних строків для розрахункових операцій, які пов'язані з міжнародним товарооборотом;

- запровадження лімітів на проведення деяких валютних операцій;

- продаж частини від іноземних надходжень і ряд інших заборон.

Основними досягненнями після введення закону можна вважати новий порядок обміну української валюти (валютний обмін он лайн), а також розширення можливостей імпортних та експортних операцій з представниками корпорацій та бізнесу Європейського Союзу. Національний банк України наголошує, що кінцевою метою інновацій $€$ зняття всіх існуючих обмежень та перехід до вільного руху капіталу. Тому новий закон є більш вільним та гнучким, а процес обміну валюти спрощений для задоволення сучасних потреб. 
Ми повністю погоджуємось із думкою про те, що Україні слід активніше долучатись до міжнародного руху капіталу, залучаючи іноземні позики. Розвиток міжнародного кредитування пов'язаний із посиленням глобалізації. Однією з проблем України є відсутність представництва на міжнародному валютному ринку в останні роки. Однією з головних причин ситуації, що склалася в країні, є слабка національна економіка.

У такій ситуації НБУ повинен суворо контролювати гривню, оскільки скасування більшості обмежень на торгівлю національною валютою, що застосовуються в даний час у прямій чи опосередкованій формі, може негативно вплинути на ії стабільність. Також ресурси українських банків настільки обмежені, що вони не можуть говорити про здійснення валютних операцій на міжнародних біржах [3].

Отже, після детального дослідження розвитку торгівлі іноземною валютою, ми можемо зробити висновок, що зміни законодавчої бази необхідні для ефективного та дієвого механізму торгівлі іноземною валютою, що представляє Україну на міжнародній арені торгівлі іноземною валютою, посилення фінансової спроможності та більш доступна система засобів переказу іноземної валюти на міжнародному рівні. Для подолання неефективності сучасної валютно-фінансової системи України варто звернути увагу на світовий досвід торгівлі іноземною валютою.

Сфера вдосконалення механізмів валютного регулювання включає:

зменшення переліку нормативно-правових актів грошовокредитного регулювання та зосередження уваги на обмеженій кількості законів та постанов;

підтримування ліквідності банківського сектору на рівні, який необхідний для здійснення валютних розрахунків ЗЕД;

зниження рівня долара, за допомогою підтримування стабільності національної валюти;

скасування обов'язкових продажів частини валютних надходжень суб'єкта господарювання;

посилення контролю за вилученням офшорного капіталу;

створення привабливих умов для населення для утримання ними валюти в українській банківській системі.

1. Про валюту і валютні операції : Закон України від 21.06.2018 № 2473-VIII. URL: https://zakon.rada.gov.ua/laws/show/2473-19\#Text (дата звернення: 14.12.2020). 2. Новікова К. І., Новікова Л. Ф. Проблеми та перспективи розвитку ринку валютних операцій в Україні. Вісник Академії митної служби України. Сер. Економіка. 2015. № 2. C. 81-87. URL: http://nbuv.gov.ua/UJRN/vamsue_2015_2_10 (дата звернення: 
24.12.2020). 3. Віблий П.І., Горбова Х. В., Федак Б.А. Проблеми валютного регулювання в Україні. Вісник Національного університету «Львівська політехніка». Менеджмент та підприємництво в Україні : етапи становлення і проблеми розвитку. 2015. № 819. С. 368-372. URL: http://nbuv.gov.ua/UJRN/VNULPM_2015_819_49. (дата звернення: 14.12.2020). 4. Крупко Я. Деякі питання вдосконалення валютного законодавства України. Підприємство, господарство і право. 2018. № 8. С. 149-151. 5. Положення «Про заходи захисту та визначення порядку здійснення окремих операцій в іноземній валюті»: Постанова Національного банку України від 02.01.2019 № 5. URL: https://zakon.rada.gov.ua (дата звернення: 14.12.2020).

\section{REFERENCES:}

1. Pro valiutu i valiutni operatsii : Zakon Ukrainy vid 21.06.2018 № 2473-VIII. URL: https://zakon.rada.gov.ua/laws/show/2473-19\#Text (data zvernennia: 14.12.2020). 2. Novikova K. I., Novikova L. F. Problemy ta perspektyvy rozvytku rynku valiutnykh operatsii v Ukraini. Visnyk Akademii mytnoi sluzhby Ukrainy. Ser. Ekonomika. 2015. № 2. S. 81-87. URL: http://nbuv.gov.ua/UJRN/vamsue_2015_2_10 (data zvernennia: 24.12.2020). 3. Viblyi P. I., Horbova Kh. V., Fedak B. A. Problemy valiutnoho rehuliuvannia v Ukraini. Visnyk Natsionalnoho universytetu «Lvivska politekhnika». Menedzhment ta pidpryiemnytstvo $v$ Ukraini : etapy stanovlennia i problemy rozvytku. 2015. № 819. S. 368-372. URL: http://nbuv.gov.ua/UJRN/VNULPM_2015_819_49. (data zvernennia: 14.12.2020). 4. Krupko Ya. Deiaki pytannia vdoskonalennia valiutnoho zakonodavstva Ukrainy. Pidpryiemstvo, hospodarstvo i pravo. 2018. № 8. S. 149-151. 5. Polozhennia «Pro zakhody zakhystu ta vyznachennia poriadku zdiisnennia okremykh operatsii v inozemnii valiuti»: Postanova Natsionalnoho banku Ukrainy vid 02.01.2019 № 5. URL: https://zakon.rada.gov.ua (data zvernennia: 14.12.2020).

Zaiachkivska O. V. [1; ORCID ID: 0000-0002-8792-9204] Candidate of Economics (Ph.D.), Associate Professor of the Department of Finance and Economic Security,

Khibeba B. M. ${ }^{[1]}$, Senior Student

${ }^{1}$ National University of Water and Environmental Engineering, Rivne

\section{FOREIGN EXCHANGE TRANSACTIONS IN THE CONTEXT OF FOREIGN ECONOMIC ACTIVITY}

The publication is devoted to the study of trends in currency regulation in Ukraine. A detailed analysis of the peculiarities of currency regulation is carried out. The article focuses on the introduction of the new Law of Ukraine «On Currency and Currency Transactions», which was adopted to replace the Decree «On the system of currency regulation», provides a comparison of their main provisions. The key problems that affect the development of foreign exchange transactions are outlined. Based on the 
study, the authors suggest ways to improve the mechanism of currency regulation.

For an effective and efficient mechanism for conducting foreign exchange transactions, it is necessary to amend the legal framework, it is also necessary to represent Ukraine in the international arena as a participant in foreign exchange transactions, strengthen the financial capacity of banks and make more accessible the system of international currency transfer. To overcome the inefficiency of the modern monetary and financial system of Ukraine, it is necessary to pay attention to the world experience of foreign exchange transactions.

The areas of improvement of the mechanism of currency regulation include: reduction of the list of normative-legal acts of currency regulation and their concentration in a limited number of laws and resolutions; maintaining the liquidity of the banking sector at the level required for foreign exchange settlements; reducing the degree of dollarization by maintaining the stability of the national currency; abolition of mandatory sale of part of foreign exchange earnings of legal entities; strengthening control over the withdrawal of capital offshore; creation of attractive conditions for the population to keep currency in the banking system of Ukraine.

Keywords: currency regulation; foreign economic activity; currency operations.

Заячкивская О. В. ${ }^{[1 ; 0 R C I D ~ I D: ~ 0000-0002-8792-9204], ~}$ к.э.н., доцент кафедры финансов и экономической безопасности Хибеба Б. Н. ${ }^{[1]}$, соискатель высшего образования первого (бакалаврского) уровня

${ }^{1}$ Национальный университет водного хозяйства и природопользования, г. Ровно

\section{ВАЛЮТНЫЕ ОПЕРАЦИИ В КОНТЕКСТЕ ВНЕШНЕЭКОНОМИЧЕСКОЙ ДЕЯТЕЛЬНОСТИ}

Публикация посвящена изучению тенденций валютного регулирования в Украине. Проведен детальный анализ особенностей осуществления валютного регулирования. В статье основное внимание уделено введению в действие нового Закона Украины «О валюте и валютных операциях», который принято на смену Декрета «0 системе валютного регулирования», предоставлено сравнение их основных положений. Определены ключевые проблемы, которые влияют на развитие валютных операций. На основании проведенного исследования авторы предлагают направления совершенствования механизма валютного регулирования. 
Для эффективного и действенного механизма реализации валютных операций нужно внести изменения в законодательную базу, также необходимо представлять Украину на международной арене как участника валютных операций, усилить финансовую мощь банков страны и сделать более доступной систему средств перевода валютных средств на международном уровне. Для преодоления неэффективности современной валютно-финансовой системы Украины нужно обратить внимание на мировой опыт проведения валютных операций.

К направлениям совершенствования механизма валютного регулирования можно отнести: уменьшение перечня нормативноправовых актов валютного регулирования и их концентрация В ограниченном количестве законов и постановлений; поддержка ликвидности банковского сектора на уровне, необходимом для проведения валютных расчетов ВЭД; снижение степени долларизации с помощью поддержания устойчивости национальной валюты; отмены обязательной продажи части валютной выручки юридических лиц; усиление контроля над выводом капитала в офшоры; создание привлекательных условий для хранения населением валюты В банковской системе Украины.

Ключевые слова: валютное регулирование; внешнеэкономическая деятельность; валютные операции. 